\title{
Detection of human bocavirus and human metapneumovirus by real-time PCR from patients with respiratory symptoms in Southern Brazil
}

\author{
Diogo André Pilger ${ }^{1+}$, Vlademir Vicente Cantarelli², Sérgio Luis Amantea ${ }^{3}$, Sandra Leistner-Segal ${ }^{4}$
}

${ }^{1}$ Faculdade de Farmácia ${ }^{4}$ Hospital de Clínicas de Porto Alegre, Universidade Federal do Rio Grande do Sul, Porto Alegre, RS, Brasil

${ }^{2}$ Universidade Feevale, Novo Hamburgo, RS, Brasil ${ }^{3}$ Irmandade Santa Casa de Misericórdia de Porto Alegre, Porto Alegre, RS, Brasil

The introduction of newer molecular methods has led to the discovery of new respiratory viruses, such as human metapneumovirus (hMPV) and human bocavirus $(\mathrm{hBoV})$, in respiratory tract specimens. We have studied the occurrence of $h M P V$ and $h B o V$ in the Porto Alegre (PA) metropolitan area, one of the southernmost cities of Brazil, evaluating children with suspected lower respiratory tract infection from May 2007-June 2008. A real-time polymerase chain reaction method was used for amplification and detection of $h M P V$ and $h B o V$ and to evaluate coinfections with respiratory syncytial virus (RSV), influenza A and B, parainfluenza 1, 2 and 3, human rhinovirus and human adenovirus. Of the 455 nasopharyngeal aspirates tested, $h M P V$ was detected in $14.5 \%$ of samples and $h B o V$ in $13.2 \%$. A unique causative viral agent was identified in $46.2 \%$ samples and the coinfection rate was $43.7 \%$. For hBoV, $98.3 \%$ of all positive samples were from patients with mixed infections. Similarly, $84.8 \%$ of all hMPV-positive results were also observed in mixed infections. Both hBoV and hMPV usually appeared with RSV. In summary, this is the first confirmation that $h M P V$ and $h B o V$ circulate in $P A$; this provides evidence of frequent involvement of both viruses in children with clinical signs of acute viral respiratory tract infection, although they mainly appeared as coinfection agents.

Key words: human metapneumovirus - human bocavirus - real-time PCR - respiratory tract infection

Respiratory tract infections are caused mostly by viruses, including respiratory syncytial virus (RSV), influenza viruses A (FLU A) and B (FLU B), parainfluenza viruses (PIV), human adenovirus (ADV) and human rhinoviruses (RNV). Recently, with the advent of molecular techniques and the introduction of these methods into the clinical laboratory, new respiratory viruses, such as the human metapneumovirus (hMPV) and human bocavirus $(\mathrm{hBoV})$, were identified in respiratory tract specimens collected from patients with clinical symptoms of respiratory diseases (Neske et al. 2007). $\mathrm{hBoV}$ is the latest pathological parvovirus discovered in Sweden, isolated from pooled nasopharyngeal aspirate specimens (Allander et al. 2007). The incidence rates are between $3 \%$ and $19 \%$ in respiratory samples from children with acute respiratory disease. However, the pathogenic role of $\mathrm{hBoV}$ is not clear because other viruses have been frequently detected in $\mathrm{hBoV}$-positive samples from children with acute respiratory tract infection (ARTI) (Longtin et al. 2008). Similarly, hMPV is a new member of the Paramyxoviridae family, Pneumovirus subfamily (Chan et al. 2007), showing a incidence rate between 3.9-9\% in young children with ARTI (Manoha et al. 2007). Molecular techniques are powerful tools to search for respiratory pathogens that may be present in clinical samples, espe-

\footnotetext{
Financial support: Laboratório Weinmann SA + Corresponding author: pilger@terra.com.br Received 11 June 2010

Accepted 10 November 2010
}

cially from patients suffering from respiratory infections (Manning et al. 2006). We have studied the occurrence of $\mathrm{hBoV}$ and hMPV in the Porto Alegre (PA) metropolitan area, one of the southernmost cities of Brazil, evaluating children suspected to have a lower respiratory tract infection during a 13-month period.

\section{PATIENTS, MATERIALS AND METHODS}

Studied population - This study included infants ( $<24$ months) admitted to the paediatric emergency room of Santo Antônio Children's Hospital, PA, who presented clinical signs of viral respiratory tract infection with lower airway obstruction, together with widespread crackles and/or wheezing. Nasopharyngeal aspirates were prospectively collected from May 2007June 2008. This routine has been applied to all patients when a viral respiratory tract infection was suspected. For all eligible cases, a specific questionnaire was completed. The study was approved by the Ethical Committee of Clinical Hospital of Porto Alegre (06-549).

Nucleic acid extraction and cDNA synthesis - A total of 455 nasopharyngeal aspirates (NPA) were kept frozen at $-70^{\circ} \mathrm{C}$ and were used for total nucleic acid extraction with the QIAmp UltraSens Virus Kit (Qiagen).

Real-time polymerase chain reaction (PCR) - A twostep reverse-transcriptase PCR method was used for amplification and detection of RNA viruses (RSV, FLU A and B, PIV 1, 2 and 3, RNV and hMPV). The reverse transcription step was performed using random hexamers and SuperScript III First-Strand (Invitrogen), according to the manufacturer's recommended protocol. Multiplex real-time PCR assays were developed in two panels: RSV, FLU A and B (panel 1) and PIV 1, 2 and 3 (panel 2). The other viruses (RNV, ADV, hBoV and hMPV) 
were detected by a singleplex virus-specific PCR. All amplifications and detections were performed using the LightCycler instrument (Roche Diagnostics) and identification of individual viruses was assessed by melting curve analysis. Primers were specifically designed from consensus genome regions obtained from the DNA Data Bank of Japan; they have closely matched annealing temperatures so that virtually identical conditions could be applied for the PCR cycle (Table I).

\section{RESULTS}

In total, 455 NPAs collected from 433 patients spanning a one-year period were tested. The average age of the study population was $5.46(4.90-6.02)$ months and $57.6 \%$ were male. Only $\mathrm{hBoV}$ was influenced by age. The average age of $\mathrm{hBoV}$-positive children was 7.5 months and the average age of $\mathrm{hBoV}$-negative children was 5.1 months $(\mathrm{p}<0.05)$. The average age of hMPVpositive was 5.9 months, whereas hMPV-negative was 5.4. hMPV and the other viruses included in this study showed no significant difference between positive and negative samples. When we evaluated the influence of gender, no significance differences for any of the viruses were seen, even considering the fact that male patients were more frequently infected with all viruses. Of the 455 samples tested, 409 (89.9\%) were positive for at least one of the 10 respiratory viruses tested in this protocol. RSV was detected in 222 samples (49.3\%), FLU A in 94 (20.9\%), FLU B in 30 (6.7\%), PIV 1 in seen (1.6\%), PIV 2 in $2(0.4 \%)$, PIV 3 in $26(5.8 \%), \mathrm{ADV}$ in nine $(2 \%)$, RNV in 112 (24.9\%), hMPV in $66(14.5 \%)$ and $\mathrm{hBoV}$ in $60(13.2 \%)$. A unique causative viral agent was identified in 201 (44.2\%) samples. Of these 409 virus-positive samples, 199 were also positive for additional viruses,

\section{TABLE I}

Primer sequences designed for real-time polymerase chain reaction and melting temperatures of each virus (de novo)

\begin{tabular}{|c|c|c|c|}
\hline Virus & Sequence $\left(5^{\prime} \rightarrow 3^{\prime}\right)$ & $\begin{array}{l}\text { Target } \\
\text { gene }\end{array}$ & $\begin{array}{l}\text { Melting } \\
\text { temperature } \\
\left({ }^{\circ} \mathrm{C}\right)\end{array}$ \\
\hline RSV & $\begin{array}{l}\text { RSV-LC-F1: TGGGAGAGGTAGCTCCAGAA } \\
\text { RSV-LC-R: CAGATCTRTCCCCTGCTGCT }\end{array}$ & Nucleo-capsid protein & 78.4 \\
\hline FLU A & $\begin{array}{l}\text { INFA-LC-F: TCACCATTGCCTTCYCTTCC } \\
\text { INFA-LC-R: CTGCTTCTCCAAGCGAATCT }\end{array}$ & Nuclear export protein & 80.8 \\
\hline FLU B & $\begin{array}{l}\text { INFB-LC-F: CTGATGTCCATCAAGCTCCA } \\
\text { INFB-LC-R: CCTTTGACATCTGCATCACG }\end{array}$ & Nucleoprotein & 84.9 \\
\hline PIV 1 & $\begin{array}{l}\text { PIV1-LC-F: GGAAAACAAWTAGTTCATATTGGTC } \\
\text { PIV1-LC-R: TGCATTGTTGTTGCAATCAGT }\end{array}$ & Hemagglutinin-neuraminidase & 79.9 \\
\hline PIV 2 & $\begin{array}{l}\text { PIV2-LC-F: TGATGGAATCAATCGCAAAA } \\
\text { PIV2-LC-R: GAAAGCAAGTCTCAGTTCAGCTA }\end{array}$ & Hemagglutinin-neuraminidase & 76.9 \\
\hline PIV 3 & $\begin{array}{l}\text { PIV3-LC-F: AATCGAGAGTRAACCCAGTCATAA } \\
\text { PIV3-LC-R1: TGTTATAGTGTGTAATGCAGCTYGT }\end{array}$ & Hemagglutinin-neuraminidase & 82 \\
\hline ADV & $\begin{array}{l}\text { ADNU-LC-F: TTCCCCATGGCNCACAAYAC } \\
\text { ADNU-LC-R: TGCCKRCTCATRGGCTGRAAGTT }\end{array}$ & Hexon protein & 84.7 \\
\hline RNV & $\begin{array}{c}\text { RNV-A-LC-F1: TAGTAGACCTGGCAGATGAGG } \\
\text { RNV-A-LC-R1: ACACGGGGCTCTTCRCAC } \\
\text { RNV-A-LC-F2: TACTAAACCTGGCAGATGAGG } \\
\text { RNV-A-LC-R2: ACAATAGGCTCTTCACAC }\end{array}$ & 5' UTR & 86 \\
\hline hMPV & $\begin{array}{l}\text { HMPV-LC-F11: ATGGCAAAGCATTAGGCTCA } \\
\text { HMPV-LC-R11: TGTTGGATGACCTGGCAAT } \\
\text { HMPV-LC-R12: TGTTAGATGACCTGGCAAT } \\
\text { HMPV-LC-R13: TGTTAGATGACCTGGCGAT }\end{array}$ & Nonfunctional nucleoprotein & 81.3 \\
\hline $\mathrm{hBoV}$ & $\begin{array}{l}\text { HBOV-LC-F1: GTCCAGAAAGAGGGGAGAGG } \\
\text { HBOV-LC-R1: GCTGATTGGGTGTTCCTGAT }\end{array}$ & Nucleoprotein 1 & 86.1 \\
\hline
\end{tabular}

ADV: human adenovirus; FLU: influenza virus; hBoV: human bocavirus; hMPV: human metapneumovirus; PIV: parainfluenzaviruses; RNV: human rhinoviruses; RSV: respiratory syncytial virus. 
resulting in a coinfection rate of $43.7 \%$. Double infections were detected in 144 (31.6\%) samples, triple infections were identified in 47 samples $(10.3 \%)$ and eight $(1.8 \%)$ samples showed four different viruses.

Among the 201 samples positive for a single virus, $122(60.7 \%)$ were positive only for RSV, $40(19.9 \%)$ only for FLU A, 18 (8.9\%) only for RNV, 10 (4.9\%) only for hMPV, four (2\%) only for FLU B, four (2\%) only for PIV 3 , two $(1 \%)$ only for PIV 1 and one $(0.5 \%)$ only for $\mathrm{hBoV}$. The other pathogens were not identified alone. Interestingly, both $\mathrm{hBoV}$ and $\mathrm{hMPV}$ were far more frequently found in mixed viral infections. For $\mathrm{hBoV}, 98.3 \%$ of all positive samples (59 cases) were from patients with mixed infections. Similarly, $84.8 \%$ of all hMPV-positive (56 cases) results were also observed in mixed infection. Both $\mathrm{hBoV}$ and hMPV normally appeared with RSV.

The temporal distribution for all viruses during the 2007-2008 period showed that the majority of the viral episodes were more frequent in June-July 2007 and June 2008 (61.1\% of all cases), which represents the winter months in the Southern Hemisphere. In this period, hMPV showed a peak of infection $(\mathrm{n}=18)$ that overlapped with the RSV-associated peak $(\mathrm{n}=56)$. In the $\mathrm{hBoV}$ analyses, we observe that the peak of infection (n $=22$ ) overlapped with the RSV distribution in both years, again correlating with the winter season. The monthly distributions of the viruses detected over a 13 -month period in this study are shown in Table II and Figure.

\section{DISCUSSION}

In this study, hMPV was found in $14.5 \%$ of all children with suspected lower respiratory tract infection. The prevalence found in our study is similar to the $4-18 \%$ prevalence reported elsewhere using real-time
PCR methods (Boivin et al. 2003, Mullins et al. 2004, Xepapadaki et al. 2004, Kuypers et al. 2005). Do Carmo Debur et al. (2007) studied hospitalized children with ARTI in Curitiba, Brazil, and found a prevalence of $6.4 \%$ for hMPV (do Carmo Debur et al. 2007). Da Silva et al. (2008) assessed the presence of hMPV in NPAs from children with ARTI and reported that this virus caused $5.6 \%$ of cases in the region of Campinas, Brazil (da Silva et al. 2008). It is interesting to note that Curitiba and Campinas are located north of PA and the lower infection rates found by these authors could be related to other variables, such as population density, socioeconomic factors and climate changes.

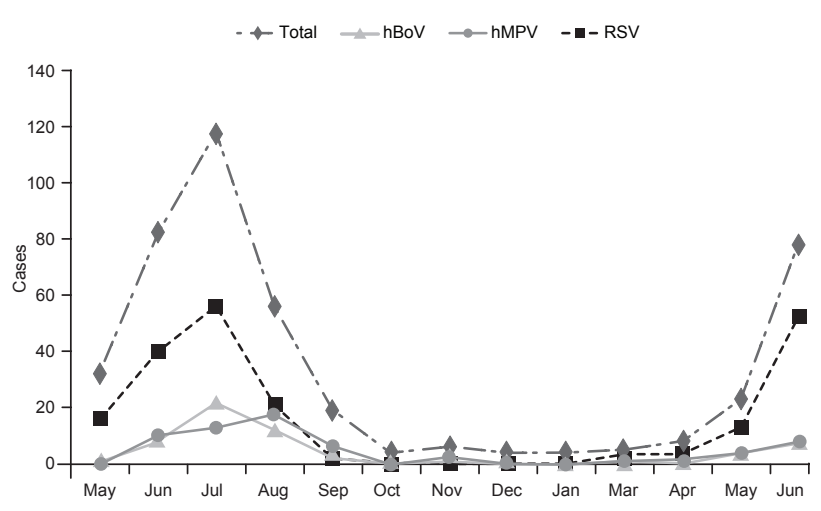

Monthly distributions of respiratory syncytial virus (RSV), human bocavirus (hBoV) and human metapneumovirus (hMPV) infection. Total: all samples analyzed in the month. $\mathrm{hBoV}$ : $\mathrm{hBoV}$ frequency in the month; hMPV: hMPV frequency in the month; RSV: RSV frequency in the month.

TABLE II

Monthly distributions for all viruses over 13-month study period

\begin{tabular}{|c|c|c|c|c|c|c|c|c|c|c|c|c|}
\hline & & Total & $\mathrm{hBoV}$ & hMPV & RNV & FLU A & FLU B & RSV & PIV 1 & PIV 2 & PIV 3 & ADV \\
\hline \multirow{8}{*}{2007} & May & 32 & 1 & 0 & 10 & 3 & 1 & 16 & 1 & 1 & 0 & 0 \\
\hline & Jun & 82 & 8 & 9 & 12 & 21 & 1 & 40 & 2 & 0 & 1 & 1 \\
\hline & Jul & 118 & 22 & 13 & 18 & 32 & 8 & 56 & 2 & 1 & 12 & 1 \\
\hline & Aug & 56 & 12 & 18 & 22 & 13 & 7 & 21 & 1 & 0 & 10 & 2 \\
\hline & Sep & 19 & 2 & 6 & 10 & 5 & 2 & 2 & 0 & 0 & 3 & 1 \\
\hline & Out & 4 & 1 & 0 & 1 & 0 & 1 & 0 & 0 & 0 & 0 & 0 \\
\hline & Nov & 6 & 0 & 2 & 3 & 0 & 1 & 0 & 0 & 0 & 0 & 0 \\
\hline & Dec & 4 & 0 & 0 & 1 & 2 & 1 & 0 & 0 & 0 & 0 & 0 \\
\hline \multirow{5}{*}{2008} & Jan & 4 & 0 & 0 & 1 & 2 & 1 & 0 & 0 & 0 & 0 & 0 \\
\hline & Mar & 5 & 0 & 1 & 4 & 0 & 0 & 3 & 0 & 0 & 0 & 0 \\
\hline & Apr & 8 & 0 & 2 & 8 & 1 & 0 & 4 & 0 & 0 & 0 & 0 \\
\hline & May & 23 & 4 & 4 & 9 & 3 & 3 & 13 & 0 & 0 & 0 & 1 \\
\hline & Jun & 78 & 7 & 8 & 10 & 10 & 4 & 53 & 1 & 0 & 0 & 2 \\
\hline
\end{tabular}

there were no samples collected for February 2008. ADV: human adenovirus; FLU: influenza virus; hBoV: human bocavirus; hMPV: human metapneumovirus; PIV: parainfluenzaviruses; RNV: human rhinoviruses; RSV: respiratory syncytial virus. 
Among the $84.8 \%$ of hMPV-positive specimens that were found in association with another respiratory pathogen, RSV was the most prevalent virus, which is similar to the findings reported by others (Boivin et al. 2003, Viazov et al. 2003). Greensill et al. (2003) analyzed bronchoalveolar lavage fluids collected from infants with RSV bronchiolitis and found that $70 \%$ of them were co-infected with hMPV (Greensill et al. 2003). It has been reported that simultaneous presence of hMPV and RSV may simply reflect a considerable seasonal distribution overlap of the two viruses (Xepapadaki et al. 2004). However, another recently published study seems to indicate that the association between $\mathrm{hMPV}$ and RSV may act in concert, potentiating their pathogenic effects and exacerbating the clinical symptoms of the respiratory disease (Bouscambert-Duchamp et al. 2005). Vicente et al. (2003) did not find hMPV coinfections with other respiratory viruses in a paediatric population with ARTI, a finding that is discordant from the majority of recently published studies (Vicente et al. 2003). In the present report, hMPV was detected as a unique respiratory pathogen in only $2.2 \%$ of the cases. Surprisingly, the results obtained by Cuevas et al. (2003) in Aracajú (Northwest Brazil) showed that hMPV alone was responsible for $17 \%$ of ARTI. Although the detection of viral nucleic acid in respiratory specimens does not prove that hMPV is responsible for the clinical manifestation, the association between a respiratory tract disease and the presence of the virus suggests a causative role.

In this study, hMPV seasonal distribution was characterized by peaks within the winter period, similar to those previously observed elsewhere (Mullins et al. 2004, van den Hoogen et al. 2004, Gray et al. 2006). In another Brazilian study, do Carmo Debur et al. (2007) observed that hMPV circulated during winter and spring (do Carmo Debur et al. 2007). The seasonal occurrence of hMPV infection largely overlaps with that of RSV infections (Chan et al. 2007).

The average age of 5.9 months for hMPV-positive children in our study is different from the majority of reported data, which exhibit an average of 11.5 months (Mullins et al. 2004, Williams et al. 2004, Kuypers et al. 2005). However, it is similar to another study performed in Brazil, which reported an average age of 4.4 months. In both studies, the distribution of hMPV infection was the same for boys and girls (do Carmo Debur et al. 2007). Similar results were observed by Reina et al. (2008) in Spain.

According to the literature, the prevalence of $\mathrm{hBoV}$ infection among hospitalized children with respiratory tract infection ranges between $1.5-18.3 \%$ (Bastien et al. 2006, Kaplan et al. 2006, Allander et al. 2007). In our study, we found a prevalence of $13.2 \%$, which is one of the highest reported so far. This result may be explained by the pre-selection of children with severe clinical manifestations. Rather than geographic differences in $\mathrm{hBoV}$ circulation, this discrepancy may be explained by differences observed in the cohort studied so far. Several reports included exclusively hospitalized children while others enrolled either hospitalized or outpatient children (Pozo et al. 2007).
Results of our study show a coinfection rate of $98.3 \%$, with only one case of a single $\mathrm{hBoV}$ infection. In the majority of previous studies, the coinfection rates ranged from 18-72\% (Allander et al. 2005, Kaplan et al. 2006). RSV was the most prevalent pathogen associated with $\mathrm{hBoV}$ in all studies, including ours. In a recent report, Esposito et al. (2008) suggested that the association of $\mathrm{hBoV}$ with another respiratory pathogen would be clinically important and that the presence of this virus alone does not seems to lead to significant symptoms in children attending an emergency room (Esposito et al. 2008). The high coinfection rates may also suggest that $\mathrm{hBoV}$ could increase the pathogenicity potential of other viruses. An alternative hypothesis is that $\mathrm{hBoV}$ infection results in long-term production of the virus, even long after withdrawal of symptoms, which could facilitate the infection by other pathogens (Naghipour et al. 2007).

$\mathrm{hBoV}$ infections have been reported to occur more frequently during the cold seasons: winter and spring months (Völz et al. 2007). Our study suggests that $\mathrm{hBoV}$ also has a seasonal distribution similar to hMPV, occurring in winter months. Human parvovirus B19, the only other parvovirus that is pathogenic to humans, is also seasonal, with peak occurrences in spring and summer (Heegaard \& Brown 2002). Bastien et al. (2006) observed no seasonal prevalence, which may be reflected by the low prevalence in their study (Bastien et al. 2006). Nonetheless, as highlighted by Schildgen et al. (2008), it is very difficult to draw any definitive conclusion on the seasonal distribution of a new viral agent based only on analyses of a single season because there is much variation of the peak respiratory season from year-to-year (Schildgen et al. 2008).

Most children infected with $\mathrm{hBoV}$ are younger than 24 months, but older children may also be affected (Schildgen et al. 2008). Our work indicates that the average age is 7.5 months for $\mathrm{hBoV}$-positive children.

In line with other recent reports, our study also suggests that hMPV and $\mathrm{hBoV}$ are almost exclusively found associated with other viral pathogens (Semple et al. 2005, Ong et al. 2007). When a single sample can contain as many as three or more viruses, it becomes difficult to evaluate the individual significance of each virus. One way to solve this problem would be to quantify the viral nucleic acids. Quantitative analysis of NPAs is methodologically difficult because the quality of the specimens obtained varies from person to person depending on sampling technique and condition of patients' nasal mucosa (Christensen et al. 2008). It is important to note that all of our data were a consequence of the analysis of only one epidemic period.

In conclusion, using a real-time PCR-based technique, this study has confirmed that $\mathrm{hMPV}$ and $\mathrm{hBoV}$ circulate in the PA metropolitan area and has provided evidence of frequent involvement of both viruses in ARTI, although a causal relationship still needs to be demonstrated by including a control group of healthy individuals. 


\section{REFERENCES}

Allander T, Jartti T, Gupta S, Niesters HG, Lehtinen P, Osterback R, Vuorinen T, Waris M, Bjerkner A, Tiveljung-Lindell A, van den Hoogen BG, Hyypiä T, Ruuskanen O 2007. Human bocavirus and acute wheezing in children. Clin Infect Dis 44: 904-910.

Allander T, Tammi MT, Eriksson M, Bjerkner A, Tiveljung-Lindell A, Andersson B 2005. Cloning of a human parvovirus by molecular screening of respiratory tract samples. Proc Natl Acad Sci USA 102: 12891-12896.

Bastien N, Brandt K, Dust K, Ward D, Li Y 2006. Human bocavirus infection, Canada. Emerg Infect Dis 12: 848-850.

Boivin G, De Serres G, Côté S, Gilca R, Abed Y, Rochette L, Bergeron MG, Déry P 2003. Human metapneumovirus infections in hospitalized children. Emerg Infect Dis 9: 634-640.

Bouscambert-Duchamp M, Lina B, Trompette A, Moret H, Motte J, Andreoletti L 2005. Detection of human metapneumovirus RNA sequences in nasopharyngeal aspirates of young French children with acute bronchiolitis by real-time reverse transcriptase PCR and phylogenetic analysis. J Clin Microbiol 43: 1411-1414.

Chan PC, Wang CY, Wu PS, Chang PY, Yang TT, Chiang YP, Kao CL, Chang LY, Lu CY, Lee PI, Chen JM, Shao PL, Huang FY, Lee CY, Huang LM 2007. Detection of human metapneumovirus in hospitalized children with acute respiratory tract infection using real-time RT-PCR in a hospital in northern Taiwan. $J$ Formos Med Assoc 106: 16-24.

Christensen A, Nordbø SA, Krokstad S, Rognlien AG, Døllner H 2008. Human bocavirus commonly involved in multiple viral airway infections. J Clin Virol 41: 34-37.

Cuevas LE, Nasser AM, Dove W, Gurgel RQ, Greensil J, Hart CA 2003. Human metapneumovirus and respiratory syncytial virus, Brazil. Emerg Infect Dis 9: 1626-1628.

da Silva LH, Spilki FR, Riccetto AG, de Almeida RS, Baracat EC, Arns CW 2008. Variant isolates of human metapneumovirus subgroup B genotype 1 in Campinas, Brazil. J Clin Virol 42: 78-81.

do Carmo Debur M, Bordignon J, Duarte dos Santos CN, Vidal LR, Nogueira MB, de Almeida SM, Raboni SM 2007. Acute respiratory infection by human metapneumovirus in children in Southern Brazil. J Clin Virol 39: 59-62.

Esposito S, Bosis S, Niesters HG, Tremolati E, Sabatini C, Porta A, Fossali E, Osterhaus AD, Principi N 2008. Impact of human bocavirus on children and their families. J Clin Microbiol 46: 1337-1342.

Gray GC, Capuano AW, Setterquist SF, Sanchez JL, Neville JS, O1son J, Lebeck MG, McCarthy T, Abed Y, Boivin G 2006. Human metapneumovirus, Peru. Emerg Infect Dis 12: 347-350.

Greensill J, McNamara PS, Dove W, Flanagan B, Smyth RL, Hart CA 2003. Human metapneumovirus in severe respiratory syncytial virus bronchiolitis. Emerg Infect Dis 9: 372-375.

Heegaard ED, Brown KE 2002. Human parvovirus B19. Clin Microbiol Rev 15: 485-505.

Kaplan NM, Dove W, Abu-Zeid AF, Shamoon HE, Abd-Eldayem SA, Hart CA 2006. Human bocavirus infection among children, Jordan. Emerg Infect Dis 12: 1418-1420.

Kuypers J, Wright N, Corey L, Morrow R 2005. Detection and quantification of human metapneumovirus in pediatric specimens by real-time RT-PCR. J Clin Virol 33: 299-305.

Longtin J, Bastien M, Gilca R, Leblanc E, de Serres G, Bergeron MG, Boivin G 2008. Human bocavirus infections in hospitalized children and adults. Emerg Infect Dis 14: 217-221.
Manning A, Russell V, Eastick K, Leadbetter GH, Hallam N, Templeton K, Simmonds P 2006. Epidemiological profile and clinical associations of human bocavirus and other human parvoviruses. J Infect Dis 194: 1283-1290.

Manoha C, Espinosa S, Aho SL, Huet F, Pothier P 2007. Epidemiological and clinical features of hMPV, RSV and RVs infections in young children. J Clin Virol 38: 221-226.

Mullins JA, Erdman DD, Weinberg GA, Edwards K, Hall CB, Walker FJ, Iwane M, Anderson LJ 2004. Human metapneumovirus infection among children hospitalized with acute respiratory illness. Emerg Infect Dis 10: 700-705.

Naghipour M, Cuevas LE, Bakhshinejad T, Dove W, Hart CA 2007. Human bocavirus in Iranian children with acute respiratory infections. J Med Virol 79: 539-543.

Neske F, Blessing K, Tollmann F, Schubert J, Rethwilm A, Kreth HW, Weissbrich B 2007. Real-time PCR for diagnosis of human bocavirus infections and phylogenetic analysis. J Clin Microbiol 45: 2116-2122.

Ong BH, Gao Q, Phoon MC, Chow VT, Tan WC, Van Bever HP 2007. Identification of human metapneumovirus and Chlamydophila pneumoniae in children with asthma and wheeze in Singapore. Singapore Med J 48: 291-293.

Pozo F, García-García ML, Calvo C, Cuesta I, Pérez-Breña P, Casas I 2007. High incidence of human bocavirus infection in children in Spain. J Clin Virol 40: 224-228.

Reina J, Ferrés F, Mena A, Figuerola J, Alcoceba E 2008. Clinical and epidemiological characteristics of respiratory infections caused by human metapneumovirus in pediatric patients. Enferm Infecc Microbiol Clin 26: 72-76.

Schildgen O, Müller A, Allander T, Mackay IM, Völz S, Kupfer B, Simon A 2008. Human bocavirus: passenger or pathogen in acute respiratory tract infections? Clin Microbiol Rev 21: 291-304.

Semple MG, Cowell A, Dove W, Greensill J, McNamara PS, Halfhide C, Shears P, Smyth RL, Hart CA 2005. Dual infection of infants by human metapneumovirus and human respiratory syncytial virus is strongly associated with severe bronchiolitis. J Infect Dis 191: $382-386$

van den Hoogen BG, Osterhaus DM, Fouchier RA 2004. Clinical impact and diagnosis of human metapneumovirus infection. Pediatr Infect Dis J 23 (Suppl. 1): S25-S32.

Viazov S, Ratjen F, Scheidhauer R, Fiedler M, Roggendorf M 2003. High prevalence of human metapneumovirus infection in young children and genetic heterogeneity of the viral isolates. J Clin Microbiol 41: 3043-3045.

Vicente D, Cilla G, Montes M, Pérez-Trallero E 2003. Human metapneumovirus and community-acquired respiratory illness in children. Emerg Infect Dis 9: 602-603.

Völz S, Schildgen O, Klinkenberg D, Ditt V, Müller A, Tillmann RL, Kupfer B, Bode U, Lentze MJ, Simon A 2007. Prospective study of human bocavirus $(\mathrm{HBoV})$ infection in a pediatric university hospital in Germany 2005/2006. J Clin Virol 40: 229-235.

Williams JV, Harris PA, Tollefson SJ, Halburnt-Rush LL, Pingsterhaus JM, Edwards KM, Wright PF, Crowe JE Jr 2004. Human metapneumovirus and lower respiratory tract disease in otherwise healthy infants and children. $N$ Engl J Med 350: 443-450.

Xepapadaki P, Psarras S, Bossios A, Tsolia M, Gourgiotis D, LiapiAdamidou G, Constantopoulos AG, Kafetzis D, Papadopoulos NG 2004. Human metapneumovirus as a causative agent of acute bronchiolitis in infants. J Clin Virol 30: 267-270. 